\title{
Response of Different Wheat Genotypes to Drought And Heat Stresses During Grain Filling Stage
}

Sanaa I.M. Milad, A. I. Nawar, A. M. Shaalan*, M. Eldakak** and Jai S. Rohila $^{* * *}$

Biotechnology Lab, Department of Crop Science, Faculty of Agriculture, El Shatby, Alexandria University, Alexandria, *Faculty of Desert and Environmental Agriculture, Matrouh Branch, Alexandria University;**Department of Genetics, Faculty of Agriculture, El Shatby, Alexandria University, Alexandria, Egypt and ${ }^{* * *}$ Department of Biology and Microbiology, South Dakota State University, Brookings, SD, USA.

\begin{abstract}
7 HIS STUDY aimed to study the performance of durum and bread wheat genotypes in relation to grain filling process, under water and heat stresses. The experiment was laid out in a split plot design at Fuka Research Station, Faculty of Desert and Environmental Agriculture, Matrouh Governorate in 2011/2012 and 2012/2013 seasons. Environmental conditions were considered as the main plots and included four environments (normal, drought, heat, heat and drought conditions). Sub plots were assigned to 14 durum and bread wheat genotypes. The results revealed significant variations between studied environments for number of grains/spike, 100- grain weight and grain yield. However, number of fertile tillers $/ \mathrm{m}^{2}$ was insignificantly influenced by environments. Wheat genotypes significantly differed for the studied traits, whereas, the environment $\mathrm{x}$ genotypes interaction significantly affected number of fertile tillers and grain yield only in both seasons. Grain yield, as an average of the two seasons, was reduced by $26.03,43.07$ and $58.28 \%$ at drought, heat and combined drought and heat, respectively, compared to normal conditions. All wheat genotypes suffered with application of combined drought and heat stresses in both seasons. Wheat genotypes varied in their response to heat stress conditions where the Beni suef 3 and Sohag 3 (durum wheat) and Sids 1 and Giza 168 (bread wheat) showed comparatively higher tolerance to heat stress. Stability analysis revealed a differential response of wheat genotypes ( $b$ value) to individual or combined drought and heat stress.
\end{abstract}

Keyword: Wheat, Drought stress, Heat stress, Stress index, Stability.

Expansion of wheat production in Egypt is a necessity to supply the demands of a rapidly growing population and reduce the dependence on importing wheat. However, increasing the acreage of wheat is confronted with several obstacles including suitable soil, sufficient irrigation water in addition to the adversary climatic changes that imposes abiotic stresses that affect wheat growth and 
production. Drought and high temperature, particularly during the reproductive stages, may be detrimental for wheat yield.

Drought during the flowering stage decreases grain-set, particularly when drought occurred shortly after anthesis (Sangtarash, 2010 and Fabian et al., 2011), whereas drought during post anthesis tends to decrease grain weight (Prasad et al., 2008 'b' and Ji et al., 2010). Hence grain yield is adversely affected by drought and the decline in yield may reach up to $70 \%$ if drought occurs during early seed development in spring cultivars (Fábián et al., 2011 and Ihsan et al., 2016). Other important grain yield components were shown to be adversely affected by drought stress occurrence at different growth stages of wheat such as number of fertile spikes/ m² (Saleem, 2003; Samarah et al., 2009 and Taheri et al., 2011).

High temperature adversely affect phenological, morphological, physiological and biochemical traits, thus decreasing plant growth and yield (Kurck et al., 2007). Dupont et al. (2006) found that high temperatures during grain growth shortened and compresses stages of grain filling, reduced duration of dry matter accumulation and reduced kernel weight by $50 \%$. Prasad et al. (2008 'a') reported a decrease in time to flowering, grain set and physiological maturity in spring wheat when grown at high nighttime temperature. They added that high nighttime temperature decreased spikelet fertility, grain number, individual grain size and grain filling duration. However, high temperature often increase grain filling rate, but not enough to compensate for decreased grain filling duration (Prasad et al., 2006). Drought and high temperature often simultaneously occur in wheat growing regions of the world, including the dry-land areas in Mediterranean region, causing significant yield losses (Lott et al., 2010). The simultaneous effects of these two abiotic stresses on crop performance and yield may be quite different than the individual stress, but there are limited studies on this topic (Mittler, 2006). Shah \& Paulsen (2003) reported an additive interaction between drought and high temperature on grain weight when imposed about a week after anthesis. However, Wardlaw (2002) and Pradhan (2011) reported a hypo-additive interaction between drought and high temperature for individual grain weight.

One way to mitigate the effect of drought and high temperature stresses on post anthesis period is to select stress tolerant varieties (Wahid et al., 2007 and El-Nakhlawy et al., 2015) that would perform well under such conditions. Hexaploid wheat (Triticum aestivum L.), through its broad genetic make-up and unique evolvement from wild species, enjoy inherent sources of abiotic stress tolerant genes (Molnar et al., 2005 and Gill et al., 2006). Therefore, the present study was conducted to quantify the independent and combined effects of drought and heat stress on spring wheat genotypes at post anthesis till maturity stage.

\section{Materials and Methods}

The field experiments were conducted during 2011/2012 and 2012/2013 winter seasons at Fuka Research Station, Faculty of Desert and Environmental Agriculture, Matrouh Governorate (North West Coast of Egypt, $\mathrm{N}=31^{\circ} 04$ ', E= Egypt. J. Agron . 38, No.3 (2016) 
$27^{\circ} 54$ '). The experimental site have a Mediterranean climate with cold winter and hot dry summers.

TABLE 1. Climatic conditions during the two seasons of the experimental site.

\begin{tabular}{|l|c|c|c|c|}
\hline \multicolumn{1}{|c|}{ Month } & $\begin{array}{c}\text { Average } \\
\text { Temp } \\
\left({ }^{\circ} \mathrm{C}\right)\end{array}$ & $\begin{array}{c}\text { Min Temp } \\
\left({ }^{\circ} \mathrm{C}\right)\end{array}$ & $\begin{array}{c}\text { Max Temp } \\
\left({ }^{\circ} \mathrm{C}\right)\end{array}$ & $\begin{array}{c}\text { Precipitation } \\
(\mathbf{m m})\end{array}$ \\
\hline \multicolumn{5}{|c|}{$\mathbf{2 0 1 1 / 1 2}$ season } \\
\hline December 2011 & 15 & $8-16$ & $13-22$ & 15.1 \\
\hline January 2012 & 13 & $7-14$ & $12-25$ & 10.54 \\
\hline February 2012 & 13 & $5-14$ & $14-21$ & 5.42 \\
\hline March 2012 & 15 & $7-13$ & $15-27$ & 4.23 \\
\hline April 2012 & 19 & $9-19$ & $17-33$ & 0 \\
\hline May 2012 & 21 & $11-22$ & $21-35$ & 0 \\
\hline \multicolumn{7}{|c|}{$\underline{\mathbf{2 0 1 2 / 1 3} \text { season }}$} \\
\hline December 2012 & 16 & $8-16$ & $19-27$ & 54.86 \\
\hline January 2013 & 14 & $7-12$ & $13-25$ & 10.92 \\
\hline February 2013 & 15 & $5-17$ & $15-26$ & 10.11 \\
\hline March 2013 & 18 & $7-17$ & $18-35$ & 0.21 \\
\hline April 2013 & 21 & $9-19$ & $21-35$ & 0 \\
\hline May 2013 & 26 & $15-23$ & $22-42$ & 0 \\
\hline
\end{tabular}

The experimental site soil had the following properties: texture $=$ sandy (calcareous), $\mathrm{pH}=8.3$, total organic matter $=0.68 \%, \mathrm{Ec}=3.4 \mathrm{dS} / \mathrm{m}$ as an average of the two seasons. In the two seasons, four experiments were set up to present normal, drought stress, heat stress and combined drought and heat stress conditions. The normal conditions experiment $\left(\mathrm{E}_{1}\right)$ included sowing on December $1^{\text {st }}$ with full irrigation water requirement during the whole season. The drought conditions experiment $\left(\mathrm{E}_{2}\right)$ included sowing on December $1^{\text {st }}$ and irrigation till $50 \%$ heading. Then withholding water supply till harvesting. The heat stress experiment $\left(\mathrm{E}_{3}\right)$ was set up with sowing in the first week of January and irrigation throughout the growing season, whereas, the combined drought and heat stress experiment $\left(\mathrm{E}_{4}\right)$ was sown on the same date and withholding irrigation after $50 \%$ heading till harvesting. Fourteen wheat genotypes were included in the present study. Those genotypes were chosen for their divergent response to drought and heat stresses. They included two local durum wheat (Triticum turgidum ssp. durum Desf. em. Musn) genotypes (Beni suef 3 and Sohag 3), nine local bread wheat (Triticum aestivum L.) genotypes ( Sakha 93, Sakha 94, Gemmiza 9, Gemmiza 10, Misr 1, Misr 2, Sids 1, Giza 168 and Sahel 1) and three introduced bread wheat genotypes (Veery, Debera and Chama). 
The experiment was laid out in a split plot design with three replications. Environmental conditions were considered as the main plots and included four environments (normal, drought, heat, heat and drought conditions). Sub plots were assigned to 14 durum and bread wheat genotypes. Plot size was $5.4 \mathrm{~m}^{2}$ (9 rows X 0.2 $\mathrm{m}$ between rows X $3.0 \mathrm{~m}$ row length). Seeding rate for all wheat genotypes was 96 $\mathrm{kg} / \mathrm{ha}$. Nitrogen fertilizer was applied as ammonium nitrate $(33.5 \% \mathrm{~N})$ at the rate of $96 \mathrm{~kg}$ N/ha. Phosphorus fertilizer was applied as calcium monophosphate $(15.5 \%$ $\mathrm{P}_{2} \mathrm{O}_{5}$ ), during land preparation, at the rate of $37 \mathrm{~kg} \mathrm{P}_{2} \mathrm{O}_{5} / \mathrm{ha}$ ). Potassium fertilizer was added as potassium sulphate $\left(48 \% \mathrm{~K}_{2} \mathrm{O}\right.$ at the rate of $60 \mathrm{~K}_{2} \mathrm{O} / \mathrm{ha}$. All other practices, such as pest control, were applied as recommended for wheat production in the region. Grain yield (GY) was measured by harvesting the inner seven rows of each plot and converted into tons/ha. Ten guarded plants were randomly taken from each plot to measure the number of grains per spike (NGS). Two random 100- grains samples were taken from each plot to measure 100-grain weight (HGW). One square meter random sample was taken from each plot at harvest to measure number of fertile tillers $/ \mathrm{m}^{2}\left(\mathrm{NFT} / \mathrm{m}^{2}\right)$.

Analysis of variance in each season, was carried out according to ElNakhlawy (2010). Stability analysis was performed according to Eberhart \& Russell (1966).

\section{Results}

Analysis of variance (Table 2) revealed significant variations between studied environments for number of grains per spike (NGS), 100-grain weight (HGW) and grain yield $(\mathrm{GY})$ whereas, number of fertile tillers $/ \mathrm{m}^{2}$ (NFT) was insignificantly influenced by environments. Wheat genotypes significantly differed for the studied four traits, whereas, the environment $\mathrm{x}$ genotypes interaction significantly influenced NFT and GY only in both seasons.

TABLE 2. Analysis of variance of the studied characters in 2011/12 and 2012/13 season.

\begin{tabular}{|c|c|c|c|c|c|}
\hline \multirow{2}{*}{ S.O.V } & \multirow{2}{*}{ D.F } & \multicolumn{5}{|c|}{ Mean squares } \\
\cline { 3 - 6 } & & NFT & NGS & HGW & GY \\
\hline \multicolumn{7}{|c|}{$\underline{\mathbf{2 0 1 1} / 12}$ season } \\
\hline Environment (E) & 3 & $1348.7 \mathrm{NS}$ & $386.01 *$ & $16.28 * *$ & $0.60 * *$ \\
\hline Error " a " & 6 & 645.9 & 79.32 & 0.94 & 0.04 \\
\hline Genotypes (G) & 13 & $3580.6 * *$ & $113.56 *$ & $1.47 * *$ & $0.04 * *$ \\
\hline E * G & 39 & $565.8 * *$ & $70.16 \mathrm{NS}$ & $0.52 \mathrm{NS}$ & $0.04 * *$ \\
\hline Error " b " & 104 & 4110.86 & 55.35 & 0.46 & 0.01 \\
\hline \multicolumn{7}{|c|}{$\mathbf{2 0 1 2 / 1 3}$ season } \\
\hline Environment (E) & 3 & $14246.0 \mathrm{NS}$ & $472.28 *$ & $2.68 \mathrm{N.S}$ & $6.37 * *$ \\
\hline Error " a " & 6 & 6822.0 & 64.22 & 1.34 & 0.43 \\
\hline Genotypes (G) & 13 & $37820.0 * *$ & $256.26 * *$ & $1.24 * *$ & $0.46 * *$ \\
\hline E* G & 39 & $5976.0 * *$ & $55.59 \mathrm{NS}$ & $0.54 \mathrm{NS}$ & $0.50 * *$ \\
\hline Error " b " & 104 & 2715.0 & 48.04 & 0.50 & 0.12 \\
\hline
\end{tabular}

NS: Not significant at $\mathrm{p} \leq 0.05,{ }^{*}$ and ${ }^{* *}$ : significant at $\mathrm{p} \leq 0.05$ and 0.01 , respectively.

Egypt. J. Agron . 38, No.3 (2016) 
Number of fertile tillers (NFT)

Insignificant differences were found between environments in the two seasons. However, a trend could be noticed where NFT decreased under stress compared to normal conditions $\left(\mathrm{E}_{1}\right)$. The highest decrease of about $29.4 \%$ resulted from subjecting wheat plants to combined drought and heat stresses (Table 3).

The response of wheat genotypes, overall environments, differed significantly. The three genotypes Sids 1, Giza 168 and Sahel 1 gave the highest NFT whereas Debera and Chama gave the lowest NFT values in both seasons. The remaining cultivars gave intermediate NFT values (Table 3).

The environment $x$ genotypes $\left(E^{*} \mathrm{G}\right)$ interaction indicated a differential response of wheat genotypes to the type of imposed stress. Under drought stress conditions $\left(\mathrm{E}_{2}\right)$, most of the genotypes showed considerable tolerance to that type of stress, where reductions in NFT values were low except for Misr 1 and Debera which suffered reductions of 23 and $28 \%$ for Misr 1, and 25 and $29 \%$ for Debera in the first and second season, respectively. Under heat stress conditions $\left(E_{3}\right)$, several genotypes maintained their high tolerance values for NFT such as Beni suef 3, Sohag 3, Misr 2 and Giza 168, in both seasons, whereas, the remaining genotypes showed an increase in reduction percentage for NFT, especially the genotype Chama which was considerably influenced by heat stress exhibiting reduction percentages of 61 and 77 in the two seasons, respectively, followed by Misr 1 genotype. Exposing wheat genotypes to combined drought and heat stresses $\left(\mathrm{E}_{4}\right)$ revealed differential responses for NFT values. Two genotypes, i.e. Beni suef 3 and Verry showed additive response (sum of reduction $\%$ for drought and heat stresses are equal to that of the combined drought and heat reduction \%). The second group of genotypes, i.e. Sohag 3, Sakha 93, Sakha 94, Gemmiza 9 and Sahel 1 showed hyper-additive response (reduction $\%$ for $\mathrm{E}_{4}$ greater than reduction $\%$ for $\mathrm{E}_{2}$ $\left.+\mathrm{E}_{3}\right)$. On the other hand, Gemmiza 10, Misr 2, Sids 1, Giza 168, Debera and Chama showed hypo-additive response (reduction $\%$ for $\mathrm{E}_{4}$ less than the sum of reduction percentages of $\mathrm{E}_{2}+\mathrm{E}_{3}$ ). One genotype, i.e. Misr 1 showed hyper-additive response in the first season and hypo-additive response in the second. Regardless of the type of response, Misr 1 and Chama suffered the highest reductions in NFT, in both seasons, while, Misr 2 and Beni suef 3 showed the highest tolerance, to the combined effect of drought and heat stresses. 


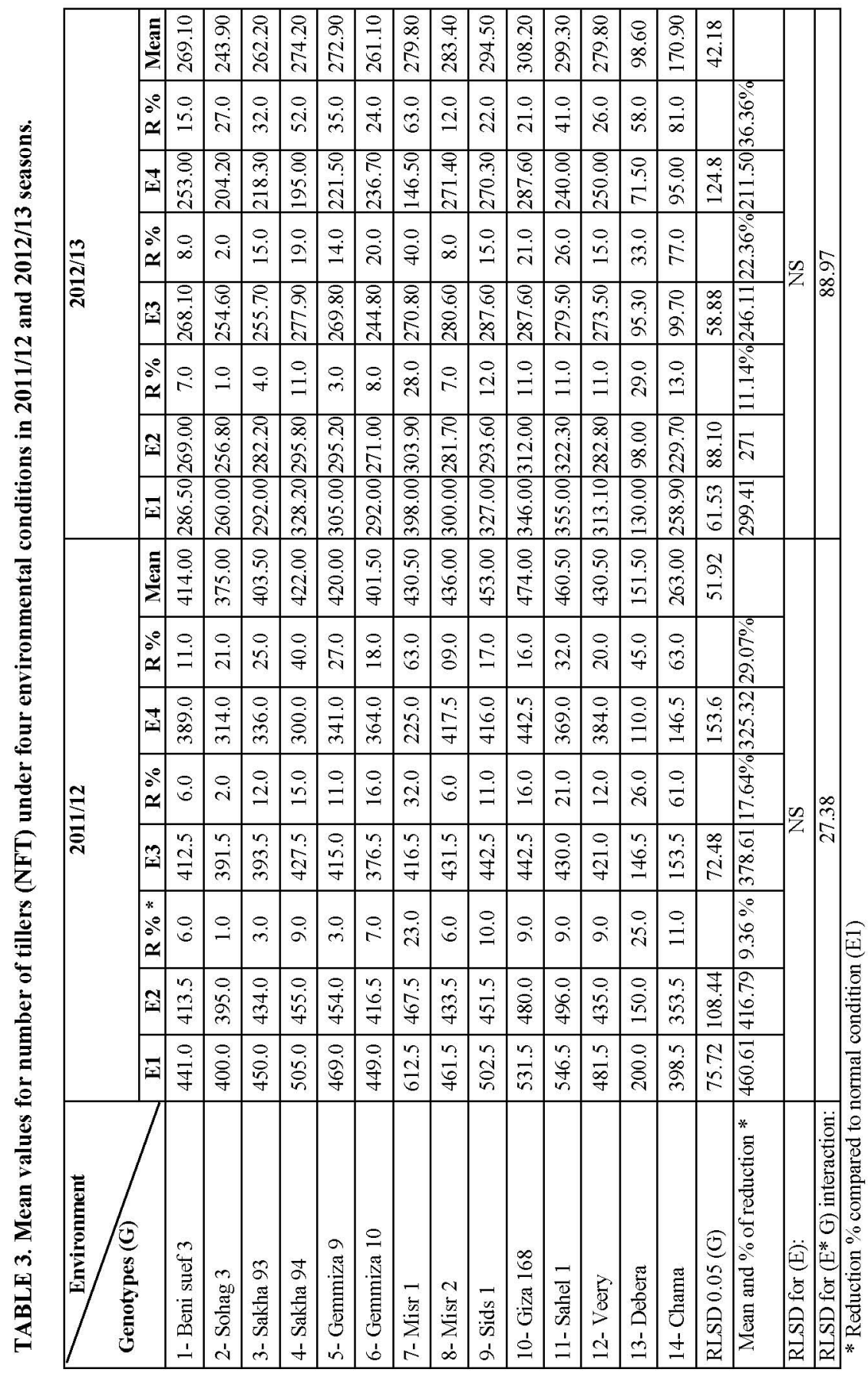


Number of grains per spike (NGS)

Number of grains per spike decreased with imposing stress conditions, as an average of wheat genotypes (Table 4). However, the decrease was significant for heat and combined drought and heat stresses compared to normal conditions. Decrease in NGS reached 21.8 and $29.9 \%$ in $\mathrm{E}_{4}$, compared to $\mathrm{E}_{1}$, in the first and second season, respectively. Concerning wheat genotypes performance, overall environments, Sahel 1 and Giza 168, in addition to Beni suef 3 and Sakha 94 had the highest values for NGS in the first season. In the second season, both Sahel 1 and Giza 168 retained their high NGS values, but Gemmiza 10 and Sids 1 replaced Beni suef 3 and Sakha 94. In both seasons, Debera and Chama genotypes gave the significantly lowest values for NGS. The environment $x$ genotypes interaction for NGS was insignificant in both seasons, indicating a similar trend of response for genotypes in the different environments. IN the first season, seven genotypes (Sohag 3, Sakha 93, Gemmiza 9, Gemmiza 10, Giza 168, Sahel 1 and Debera) suffered less than $5 \%$ in NGS in E2 compared to $E_{1}$. In E3, only three genotypes (Sakha 93, Giza 168 and Sahel 1) showed less than $5 \%$ decrease in NGS compared to $E_{1}$. Moreover, two genotypes (Giza 168 and Sahel 1) suffered less than $10 \%$ decrease in NGS in $E_{4}$ compared to $E_{1}$. Similarly, in the second season, seven genotypes in $E_{2}$, three genotypes in $E_{3}$ and three genotypes in $\mathrm{E}_{4}$ showed reduction percentages less than $5 \%, 10 \%$ and $20 \%$ compared to $E_{1}$, respectively, with Giza 168 and Sahel 1 included in each group.

\section{One-hundred grain weight (HGW)}

In the first season 2011/2012, significant differences were found between environments where stressed environments means were significantly reduced compared to $\mathrm{E}_{1}$ (Table 5). Moreover, $\mathrm{E}_{2}$ and $\mathrm{E}_{3}$ were statistically similar while $\mathrm{E}_{4}$ mean was the significantly lowest in HGW, with a reduction percent of $32.71 \%$. In 2012/2013, a similar trend was observed but the differences between environments means were significant. Significant differences were found between varietal means, overall environments, in both seasons. Veery, in the first season, and Misr 1, in the second season, recorded the highest values for HGW (4.50 and $3.72 \mathrm{~g}$, respectively). On the other hand, both Debera and Chama recorded the lowest values of HGW in both seasons.

The E x G interaction was insignificant, in both seasons, for HGW, where genotypes exhibited increasing reduction percentages in the trait from $E_{2}$ to $E_{3}$ to $\mathrm{E}_{4}$. Comparing genotypes within each environment, in the first season, indicated that Sakha 93 had the highest, whereas, Debera had the lowest, value for HGW in $\mathrm{E}_{1}$. In $\mathrm{E}_{2}$, Chama suffered the least reduction (1\%) while Sakha 93 exhibited the highest reduction $(29 \%)$ in HGW under drought stress. Under heat stress conditions $\left(\mathrm{E}_{3}\right)$, Sakha 93 gave the highest reduction $(41 \%)$ in $\mathrm{HGW}$, while Gemmiza 9, Giza 168 and Veery suffered reductions in HGW of values less than $10 \%$ under combined drought and heat stress conditions $\left(\mathrm{E}_{4}\right)$, Sakha 93 still exhibited its high sensitivity to both types of stresses with a high reduction $(56 \%)$ in HGW, whereas, both Misr 2 and Veery exhibited reduction percentages lower than $20 \%$ for that trait. In the second season, the performance of genotypes varied considerably compared to the first season. In $\mathrm{E}_{1}$, Veery had the highest, 


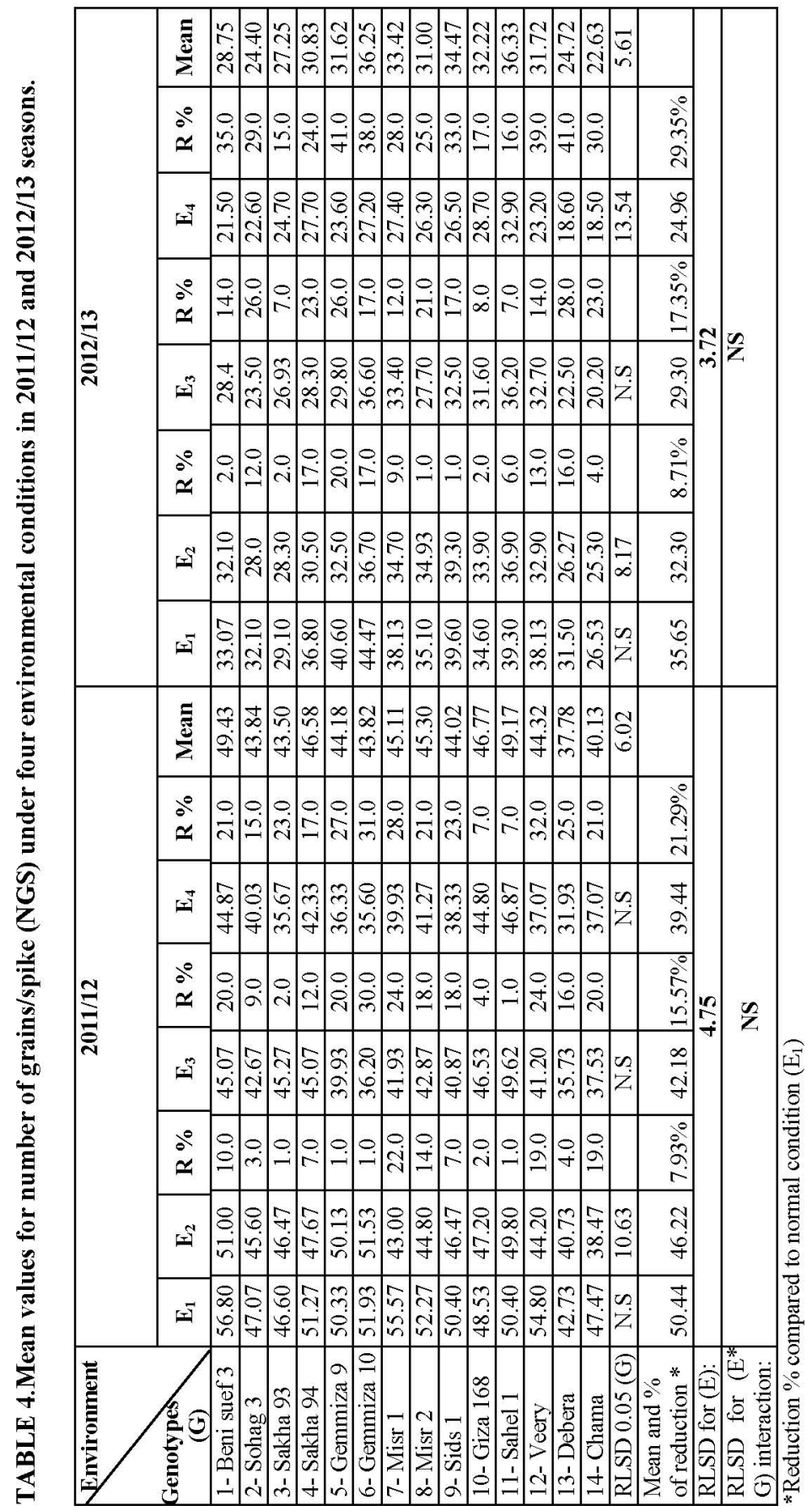

Egypt. J. Agron. 38, No.3 (2016) 
RESPONSE OF DIFFERENT WHEAT........

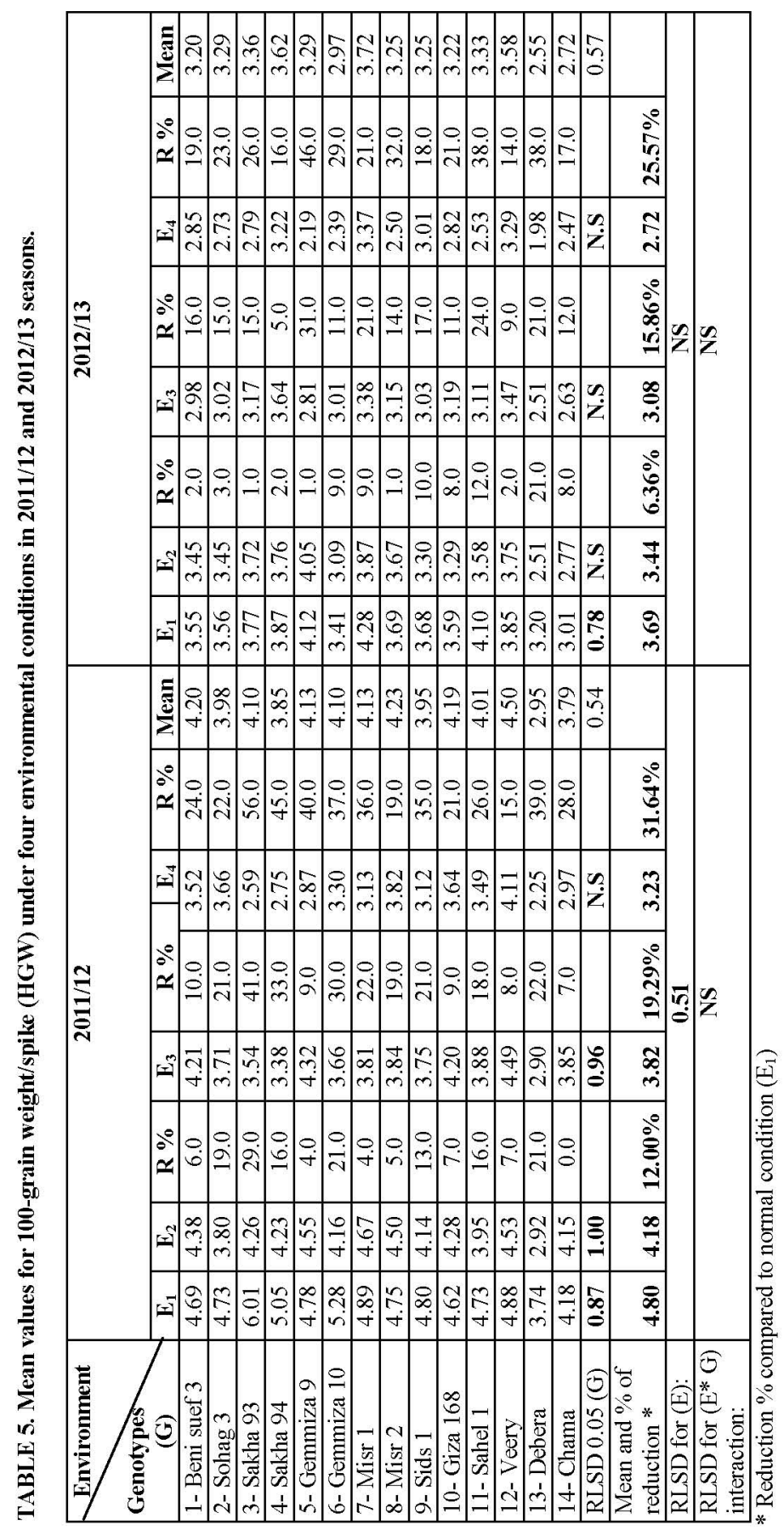

Egypt. J. Agron . 38, №. 3 (2016) 
whereas Debera had the lowest, HGW value. In $\mathrm{E}_{2}$, several genotypes suffered reductions in HGW in the range of 1 to $3 \%$ whereas Debera had the highest reduction percentage in $\mathrm{HGW}(21 \%)$. Under $\mathrm{E}_{3}$ conditions, both Sakha 94 and Veery exhibited reductions in HGW of less than $10 \%$ whereas Sahel 1 had the highest reduction percentage of 24 . In $\mathrm{E}_{4}$, Gemmiza 9 had a reduction percentage of 46 in HGW compared to Beni suef 3, Sakha 94 and Veery which exhibited less than $20 \%$ reduction in that trait.

\section{Grain yield $(G Y)$}

Mean values for grain yield, as influenced by environments, wheat genotypes and their interaction, under the four environmental conditions are presented in Table 6. Progressive decrease in grain yield was observed in stressed environments, compared to normal conditions $\left(E_{1}\right)$ from $E_{2}$ to $E_{3}$ and to $E_{4}$ in both seasons, with relatively higher magnitudes in the second season.

Overall environments, Sakha 94, bread wheat genotype, gave the highest grain yield in both seasons, and was insignificantly different from Sohag 3, Sids 1, Giza 168 and Veery. On the other hand, Beni suef 3, Gemmiza 10, Misr 1, Sahel 1 and Debera gave the lowest grain yield in both seasons. The $\mathrm{E} * \mathrm{~V}$ interaction was significant for grain yield in both seasons. The two genotypes Sids 1 and Giza 168 showed relatively high tolerance to drought and heat stresses, either individually or combined, compared to the other wheat genotypes in both seasons. On the other hand, Beni suef 3, Sohag 3 and Misr 2 showed tolerance to imposed drought and heat stresses but suffered high reduction in grain yield when subjected to the combined effect of the two stresses. The remaining genotypes were sensitive to both stresses, individually or combined, in the two seasons. The response of genotypes to combined drought and heat stresses was generally hypo-additive, except genotype Sohag 3 which showed hyper-additive response in the first season, whereas in the second season, both Sohag 3 and Giza 168 showed additive response while Sids 1 showed a relatively hyper-additive response.

Stability analysis for grain yield

Data in Table 7 revealed variations in genotypes response to the different environments with regard to the regression coefficient (b), whereas the variance component $\left(\mathrm{s}^{2} \mathrm{~d}\right)$ was insignificantly different from zero, with high coefficient of determination values $\left(\mathrm{r}^{2}\right)$ ranging from 87 to $99 \%$ in the first season and from 88 to $98 \%$ in the second season.

Genotypes Beni suef 3, Misr 1, Misr 2, Sids 1 and Giza 168 had b values significantly or high significantly, lower than 1 indicating the ability of those genotypes to perform relatively better under drought and heat stress conditions. On the other hand, Sakha 94, Veery, Debera and Chama had "b" values significantly or highly significantly, higher than 1 indicating that those genotypes perform better under normal conditions. The remaining genotypes exhibited "b" values insignificantly different from 1 , which implement a degree of stability of a genotype across tested environments, Sohag 3 would be the favorable genotypes

Egypt. J. Agron . 38, No.3 (2016) 
RESPONSE OF DIFFERENT WHEAT........

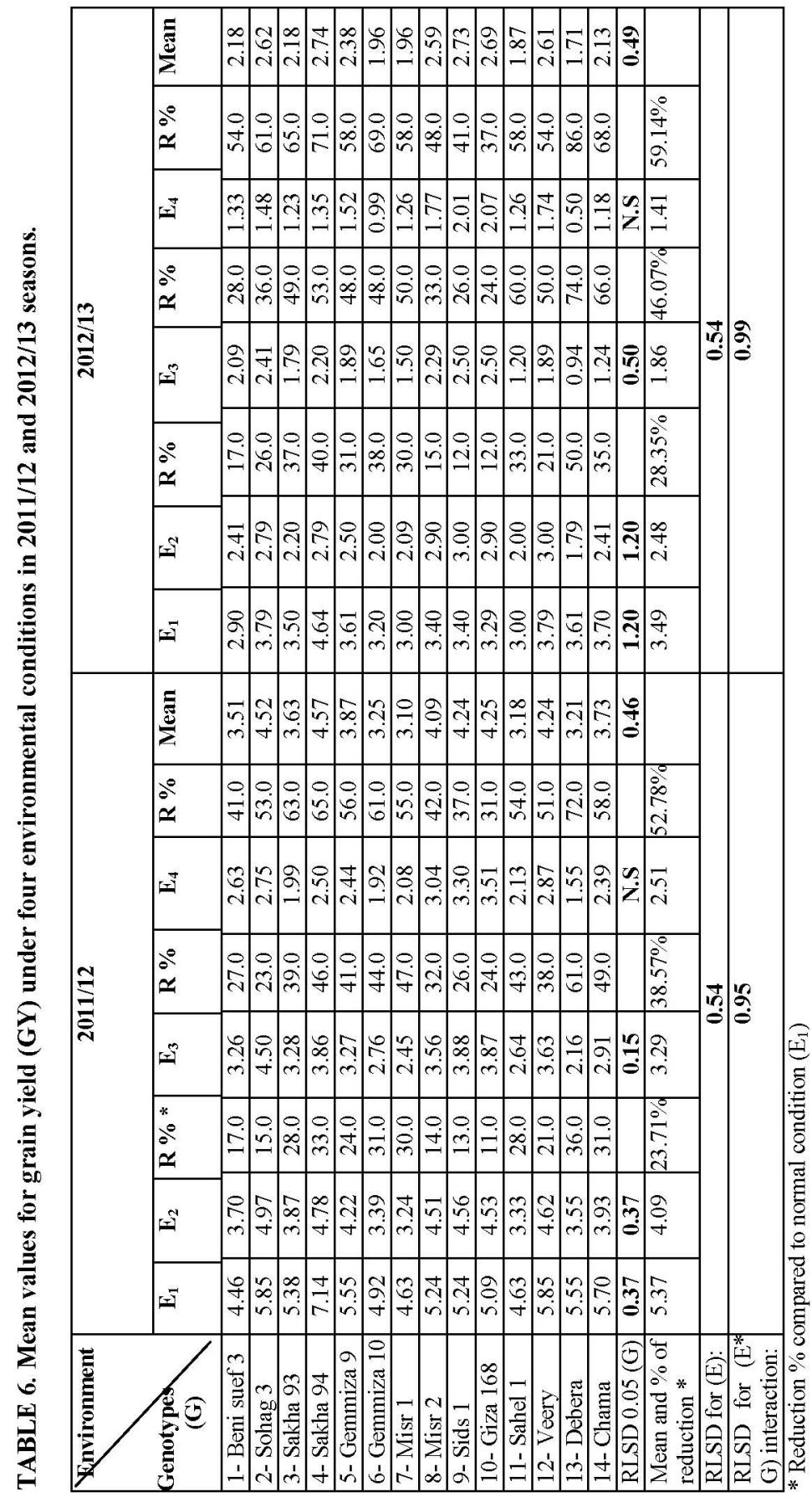

Egypt. J. Agron . 38, №. 3 (2016) 
since it exhibited stable performance across environments and high mean yield value. However, since the targeted area (North West Coast of Egypt) suffers from drought and heat stress conditions during grain set and grain filling stages, it would be imperative to identify genotypes that would perform well under these conditions. Hence, Misr 2, Sids 1 and Giza 168 genotypes would be the favorable genotypes since they exhibited better performance under drought, heat and combined drought and heat conditions, and had relatively high mean yield values.

TABLE 7. Stability of grain yield in 2011/12 and 2012/13 seasons.

\begin{tabular}{|l|l|c|c|c|c|c|c|c|}
\hline \multirow{2}{*}{ Genotypes } & \multicolumn{5}{|c|}{ Season 2011/12 } & \multicolumn{5}{c|}{ Season 2012/13 } \\
\cline { 2 - 10 } & Mean & b & $\mathbf{S}^{\mathbf{2}} \mathbf{d}$ & $\mathbf{r}^{\mathbf{2}}$ & $\mathbf{M e a n}$ & $\mathbf{b}$ & $\mathbf{S}^{\mathbf{2}} \mathbf{d}$ & $\mathbf{r}^{\mathbf{2}}$ \\
\hline 1- Beni suef 3 & 3.51 & 0.70 & 0.05 & 0.91 & 2.18 & 0.73 & 0.02 & 0.93 \\
\hline 2- Sohag 3 & 4.52 & 1.12 & 0.07 & 0.95 & 2.62 & 1.10 & 0.03 & 0.92 \\
\hline 3- Sakha 93 & 3.63 & 0.96 & 0.02 & 0.97 & 2.18 & 0.97 & 0.01 & 0.94 \\
\hline 4- Sakha 94 & 4.57 & 1.49 & 0.03 & 0.99 & 2.74 & 1.43 & 0.02 & 0.96 \\
\hline 5- Gemmiza 9 & 3.87 & 0.94 & 0.01 & 0.99 & 2.38 & 0.96 & 0.01 & 0.98 \\
\hline 6- Gemmiza 10 & 3.25 & 0.98 & 0.02 & 0.98 & 1.96 & 0.94 & 0.01 & 0.96 \\
\hline 7- Misr 1 & 3.10 & 0.79 & 0.01 & 0.98 & 1.96 & 0.76 & 0.01 & 0.95 \\
\hline 8- Misr 2 & 4.09 & 0.82 & 0.04 & 0.95 & 2.59 & 0.80 & 0.02 & 0.92 \\
\hline 9- Sids 1 & 4.24 & 0.52 & 0.01 & 0.98 & 2.73 & 0.55 & 0.02 & 0.97 \\
\hline 10- Giza 168 & 4.25 & 0.79 & 0.09 & 0.87 & 2.69 & 0.76 & 0.04 & 0.88 \\
\hline 11- Sahel 1 & 3.18 & 0.89 & 0.04 & 0.95 & 1.87 & 0.86 & 0.01 & 0.94 \\
\hline 12- Veery & 4.24 & 1.17 & 0.03 & 0.98 & 2.61 & 1.21 & 0.01 & 0.93 \\
\hline 13- Debera & 3.21 & 1.59 & 0.07 & 0.97 & 1.71 & 1.54 & 0.03 & 0.94 \\
\hline 14- Chama & 3.73 & 1.18 & 0.09 & 0.94 & 2.13 & 1.23 & 0.03 & 0.93 \\
\hline
\end{tabular}

\section{Discussion}

Drought and heat stress are among the most important environmental abiotic stresses that influence wheat growth, development and yield processes. The process of grain filling, the accumulation of reserve nutrients in the developing and maturing grain, is sensitive to environmental conditions strongly affected final yield quantitatively and qualitatively (Yang \& Zhang, 2006). The objective

Egypt. J. Agron . 38, No.3 (2016) 
of this research was to study the influences of drought and heat, independently and in combination, on grain filling and yield of durum and bread wheat genotypes in the North West coast of Egypt. That region is characterized by limited, or no rainfall and elevated temperatures during grain filling stage.

The obtained results revealed a difference between the two seasons where values of studied characters, in general, decreased in the second season, compared to the first, in range from $25 \%$ for grain weight up to $35 \%$ for number of fertile tillers, even in normal environments. That decrease may be attributed to the seasonal fluctuations in rainfall and temperature (Table 1). Temperatures in the second season were higher than the first season especially during grain setting and filling stages (March and April) leading to lower number of fertile tillers and lower grain weight. Such variations in climatic conditions between seasons is a common phenomenon in the arid regions of the Mediterranean basin (Garcia Del Moral et al., 2003). Drought stress conditions $\left(E_{2}\right)$ resulted in an average decrease, for both seasons, of $9.5 \%$ in number of fertile tillers, $9.0 \%$ in number of grains per spike, $10.0 \%$ in one hundred grain weight and $26 \%$ in grain yield. The low reduction percentages in the first three characters may be explained by the late onset of drought (beginning of grain filling stage) which allowed for normal vegetative growth before imposing of drought. That may have allowed for re-allocation of photosynthesis from the stem to the grain, thus ameliorating the effect of drought. However, the cumulative decreases in these characters (yield components) resulted in a $26 \%$ decrease in grain yield. Blum et al. (1994) concluded that efficient photosynthesis and stem reserve accumulation during the vegetative phase has a decisive role on the formation of generative organs and thus may directly affected final yield. Several investigations reported that water deficit at grain filling stage affected yield and yield components in wheat (Saleem, 2003; Peltonen- Sainio et al., 2007 and Moayedi et al., 2010). Reduction in crop yield under terminal drought stress could be due to the shorter grain filling period, lower accumulation of dry matter or by increase in the number of sterile florets and spikes (Alqudah et al., 2011 and Aslani et al., 2012). Genotypes showed variable response to drought stress conditions, where durum wheat, in general, showed comparatively lower reductions with regard to grain yield and yield components in comparison with bread wheat genotypes. However, the bread wheat genotype, Misr 2, Sids 1 and Giza 168 showed high tolerance to drought stress at grain filling stage compared to other bread wheat genotype. The differences between genotypes may be due to their yielding ability and differences in re-allocation of photosynthates from stems to grains, which are controlled by genetic constitution of the genotype. Similar findings were reported by Moayedi et al. (2010), Shamsi et al. (2011) and Aslani et al. (2012).

Under heat stress conditions $\left(\mathrm{E}_{3}\right)$, the reductions in grain yield and yield components were more pronounced than under drought stress conditions. Reduction percentages were about $18 \%$ for number of fertile tillers, number of grains per spike and one hundred grain, as an average of the two seasons. Grain yield, however, exhibited a high average reduction of $43 \%$ under heat stress 
conditions. In arid regions of the Mediterranean basin, wheat plants are subjected to evaluated temperatures during grain filling stage, in addition to period of hot winds that cause sudden increase in temperature (above $35^{\circ} \mathrm{C}$ ) for varying periods. Stone (2001) concluded that the most significant factors for heat stress related yield loss in cereals include the high- temperature induced shortening of developmental phases, reduced light perception over the shortened life cycle and perturbation of the processes associated with carbon assimilation (transpiration, photosynthesis and respiration). These processes are strongly related to production of dry matter, and dry matter reserves in the plant, that are translocate to the grains forming the final yield.

Wheat genotypes varied in their response to heat stress conditions where Beni suef 3 and Sohag 3 (durum wheat) and Sids 1 and Giza 168 (bread wheat) showed comparatively higher tolerance to heat stress. These genotypes may possess genetically controlled mechanisms that enables them to tolerat elevated temperatures such as increasing the expression of genes participating in photosynthesis, protein synthesis and the preservation of cell status (Zhang et al., 2005).

Drought and high temperature stresses often occur during the grain filling period of a wheat crop development stage, and often occur simultaneously in dry land wheat areas, such as arid regions of the Mediterranean basin, causing yield loss (Lott et al., 2011). The simultaneous effects of these two abiotic stresses on crop performance and yield may be quite different than the individual stress, but there are limited studies about how their combination impacts wheat crop productivity (Mittler, 2006). Subjecting wheat genotypes to combined drought and heat stresses $\left(\mathrm{E}_{4}\right)$ was found to have a significantly greater detrimental effect on productivity compared with each of the different stresses applied individually. Both number of grains per spike and one hundred grain weight showed additive response to combined drought and heat stresses, with average reduction percentages of 26.0 and $29.5 \%$, respectively. On the other hand, number of fertile tillers exhibited a hyper-additive response to the combined effect of both stresses, with a reduction percentage of $29.4 \%$. Grain yield, however, showed a hypo-additive response to combined drought and heat stresses with an average reduction of $55.5 \%$. Prasad et al. (2008 'b') suggested that where drought and heat stress occur concurrently after anthesis, there may be a degree of drought escape associated with heat stress because of the reduction in the duration of seed filling, even though the rate of water use may be enhanced by heat stress. That may explain the hypo-additive effect of the combined abiotic stresses.

All wheat genotypes suffered with application of combined drought and heat stresses in both seasons. Reduction percentages in grain yield ranged from $34 \%$ for Giza 168 to $79 \%$ for Debera, as an average for the two seasons. The differences between genotypes may be attributed to relative sensitivity of those genotypes to the combined effect of drought and heat with regard to duration and rate of grain filling which affect the overall temporal program of grain development (Dupont \& Altenbach, 2003).

Egypt. J. Agron . 38, No.3 (2016) 
Stability analysis revealed a differential response of wheat genotypes to individual or combined drought and heat stress. That may be attributed to the genotypic variability between wheat genotypes in terms of stress tolerance. All studied genotypes suffered progressive reduction in grain yield, compared to normal conditions, in the order of drought, heat and combined drought and heat stress environments. However, the response (b value) varied between genotypes indicating genotypic differences between wheat genotypes to tolerance, acclimate, or recover from stress. Shamsi et al. (2011) and Zahid et al. (2015) reported variations in bread wheat genotypes stability under stress conditions.

\section{Conclusions}

The results obtained from the present study revealed that responses of wheat genotypes to a combination of drought and heat stresses cannot be directly extrapolated from the response of genotypes to each of the two stresses individually. Application of a combination of the two stresses at start of grain development stage had a significantly greater detrimental effect on grain yield and yield components of wheat genotypes compared with each of the two stresses applied individually. The effect of both stresses, in general, was hypoadditive for most characters in wheat genotypes indicating that mechanisms of tolerance to both stresses may be interrelated within the wheat plants. Meanwhile, the interactive effects of heat and drought stresses on wheat plants should receive more attention in order to understand the complexity of the relationship between these two abiotic stresses especially when we consider future climate change scenarios that include extreme changes in temperature and drought.

Acknowledgments: The authors are thankful for Science and Technology Development Fund (STDF), Egypt, for financing the present research work as part of the US Egypt Cooperative Research: Gene discovery for drought and heat tolerance in wheat through proteomic approach.

\section{References}

Alqudah, A.M., Samarah, N.H. and Mullen, R.E. (2011) Drought stress effect on crop pollination, seed set, yield and quality. In: "Alternative Farming Systems, Biotechnology, Drought Stress and Ecological Fertilization”, Lichtfouse, E. (Ed). pp.193-213, Springer Science+ Business Media B.V., Sustain. Agric. Rev. 6.

Aslani, F., Mehrvar, M.R. and Juraimi, A.S. (2012) Evaluation of some morphological traits associated with wheat yield under terminal drought stress. African Journal of Agriculture Research, 7(28), 4104-4109.

Blum, A., Sinmena, B., Mayer, J., Golan, G. and Shpiler, L. (1994) Stem reserve mobilization supports wheat grain filling under heat stress. Australian Journal of Plant Physiology, 21, 771-781. 
Dupont, F. and Altenbach, S. (2003) Molecular and biochemical impacts of environmental factors on wheat grain development and protein synthesis. Journal of Cereal Science, 38, 133-146.

Dupont, F. M., Hurkman, W. J. Vensel, W. H., Tanaka, C. K., Kothari, K. M., Chung, O. K. and Al tenbach, S. B. (2006) Protein accumulation and composition in wheat grains: effects of mineral nutrients and high temperature. Europian $J$. Agronomy, 25, 96-107.

Eberhart, S.A. and Russell, W.A. (1966) Stability parameters for comparing varieties. Crop Sci. 6, 36-40.

El-Nakhlawy, F. S. (2010) "Experimental Design and Analysis in Scientific Research". Sci. Pub. Center. King Abdulaziz University, Jeddah, Saudi Arabia.

El-Nakhlawy, F.S., Alghabari, F. and Zahid, M. (2015) Response of Wheat genotypes to planting dates in the arid region. Sci. Agri. 10 (2), 59-63.

Fábián, A., Jäger, K., Raskszegi, M. and Barnbás, B. (2011) Embryo and endosperm development in wheat (Triticum aestivum L.) kernels subjected to drought stress. Plant Cell Rep. 30, 51-563.

Fernandez, G. C. J. (1992) Effective selection Criteria for assessing stress tolerance. In: Proceedings of the International Symposium on "adaptation of vegetables and other food crops in temperature and water stress". C. G. Kuo (Ed.), Publication, Tainan, Taiwan.

Garcia Del Moral, L.F., Raharrabti., Y., Villegas, D. and Royo, C. (2003) Evaluation of grain yield and its components in durum wheat under Mediterranean conditions: An ontogeny approach. Agronomy Journal, 95 (2): 266-274

Gill, B.S., Friebe, B. , Raupp, W.J., Wilson, D.L., Stan, C.T., Sears, R.G., BrownGuedira, G.L. and Fritz, A.K. (2006) Wheat genetics resource center: The first 25 years. Adv. Agron. 89, 73-136.

Ihsan, M.Z., El-Nakhlawy, F.S., Ismail, S.M., Fahad, S. and Daur, I. (2016) Wheat phenological development and growth studies as affected by drought and late season high temperature stress under arid environment. Frontiers in Plant Science, 7 Article No.795 (ISI).

Ji, X., Shiran, B.,Wan, J., Lewis, D. C., Jenkins, C. L. D., Condon, A. G., Richards, R. A. and Dolferus, R. (2010) Importance of pre-anthesis anther sink strength for maintenance of grain number during reproductive stage water stress in wheat. Plant Cell Environ. 33, 926-942.

Kurck, I., Chang, T. K., Bertain, S. M., Madrigal, A., Liu, L., Lassner, M. W. and Zhou, G. (2007) Enhanced thermostability of Arabidopsis Rubiso activase improves photosynthesis and growth rates under moderate heat stress. Plant Cell, 19, 3230-3241.

Lott, N., Ross, T., Smith, A., Houston, T. and Shein, K. (2011) Billion dollar U.S. Weather Disasters, 1980 - 2010. Available at http://www.ncdc.noaa.gov/oa/reports/billionz.html. National Climatic Data Center, Asheville, NC, USA.

Egypt. J. Agron . 38, No.3 (2016) 
Mittler, R. (2006) Abiotic stress, the field environment and stress combination. Trends Plant Sci. 11,15-19.

Moayedi, A.A., Boyce, A.N. and Barakbah, S.S. (2010) The performance of durum and bread wheat genotypes associated with yield and yield component under different water deficit conditions. Australian Journal of Basic and Applied Science, 4 (1), 106113 .

Molnar, I., Dulai, S., Csernak, A., Pronay, J. and Molnar-Lang, M. (2005) Photosynthetic responses to drought stress in different Aegilopsspecies. Acta Biologica Szegediensis, 49, 141- 142.

Peltonen- Sainio, P., Kangas, A., Salo, Y. and Jauhiainen, L. (2007) Grain number dominates grain weight in temperate cereal yield determination: Evidence based on 30 years of multi ocation trials. Field Crops Research, 100, 179-188.

Pradhan, G. P. (2011) Effects of drought and /or high temperature stress on wild wheat relatives (Aegilops Species) and Synthetic Wheats. Ph.D. Thesis, Dept. of Agronomy, College of Agric., Kansas State University.

Prasad, P. V. V., Boote, K. J. and Allen Jr, L. H. (2006) Adverse high temperature effects on pollen viability, seed-set, seed yield and harvest index of grain sorghum (Sorghum bicolor (L.) Moench.) are more severe at elevated carbon dioxide due to higher tissue temperatures. Agr. Forest Meteorol.139, 237-251.

Prasad, P. V. V., Pisipati, S. R., Mutava, R. N. and Tuinstra, M. R. (2008 'a') Impact of nighttime temperature on physiology and growth of spring wheat. Crop Sci. $\mathbf{4 8}$, 1911-1917.

Prasad, P.V.V., Staggenborg, S.A. and Ristic, Z. (2008 'b') Impacts of drought and/or heat stress on physiological, developmental, growth, and yield processes of crop plants. Response of crops to limited water: Understanding and modeling water stress effects on plant growth processes. "Advances in Agricultural Systems Modeling Series". 1. pp. 301-355.

Saleem, M. (2003) Response of durum and bread wheat genotypes to drought stress: Biomass and yield components. Asian Journal of Plant Science, 2, 290-293.

Samarah, N. H., Alqudah, A. M., Amayreh, J. A. and McAndrews, G. M. (2009) The effect of late-terminal drought stress on yield components of four barley cultivars. $J$. Agron. Crop Sci. 11, 403-411.

Sangtarash, M. H. (2010) Responses of different wheat genotypes to drought stress applied at different growth stages. Pak. J. B. Sci. 13, 114-119.

Shah, N. H. and Paulsen, G. M. (2003) Interaction of drought and high temperature on photosynthesis and grain-filling of wheat. Plant Soil, 257, 219-226.

Shamsi, K., Kobraee, S. and Rasekhi, B. (2011) Variation of yield components and some morphological traits in bread wheat grown under drought stress. Annals of Biological Research, 2 (2), 372-377. 
Stone, P. (2001) The effects of heat stress on cereal yield and quality. In: "Crop Responses and Adaptations to Temperature Stress" (A.S. Basra Ed.). pp. 243-291. Food Products Press, Binghamton. NY, USA.

Taheri, S., Saba, J., Shekari, F. and Abdullah, T. L. (2011) Effects of drought stress condition on the yield of spring wheat (Triticum aestivum) lines. Afr. J. Biotechnol. 10(80),18339-18348.

Wahid, A., Gelani, S., Ashraf, M. and Foolad, M. (2007) Heat tolerance in plants: An overview. Environ. Exp. Bot. 61, 199.223.

Wardlaw, I. F. (2002) Interaction between drought and chronic high temperature during kernel filling in wheat in controlled environment. An. Bot. 90, 469-476.

Yang, J.C. and Zhang, J.H. (2006) Grain filling of cereals under soil drying. New Phytologist, 169, 223-236.

Zahid, I., El-Nakhlawy, F.S. and Ismail , S. M. (2015) Screening Triticum aestivum L. genotypes for drought stress tolerance under arid land conditions. Journal of Arid land Agriculture, 1, 31-35.

Zhang, Y., Mian, M. A., Chekhovisky, K., So, S., Kupfer, D., Lai, H. and Roe, B. A. (2005) Differential gene expression in Festuca under heat stress conditions. J. Exp. Bot., 59, 839-848.

(Received 29/8/2016;

accepted 20/11/2016) 


\section{استجابة الطرز المختلفة من القمح للأجهاد المائى والحرارى خلال مرحلة امتلاء الحبوب المختو

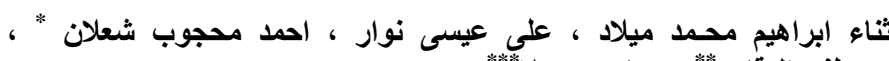

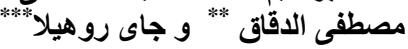

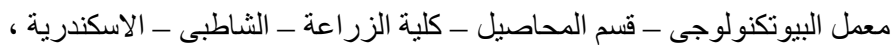

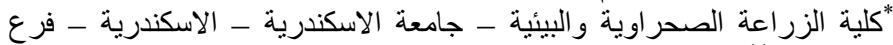

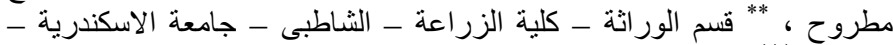

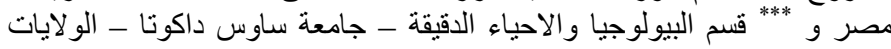 المتحدة الامريكية.}

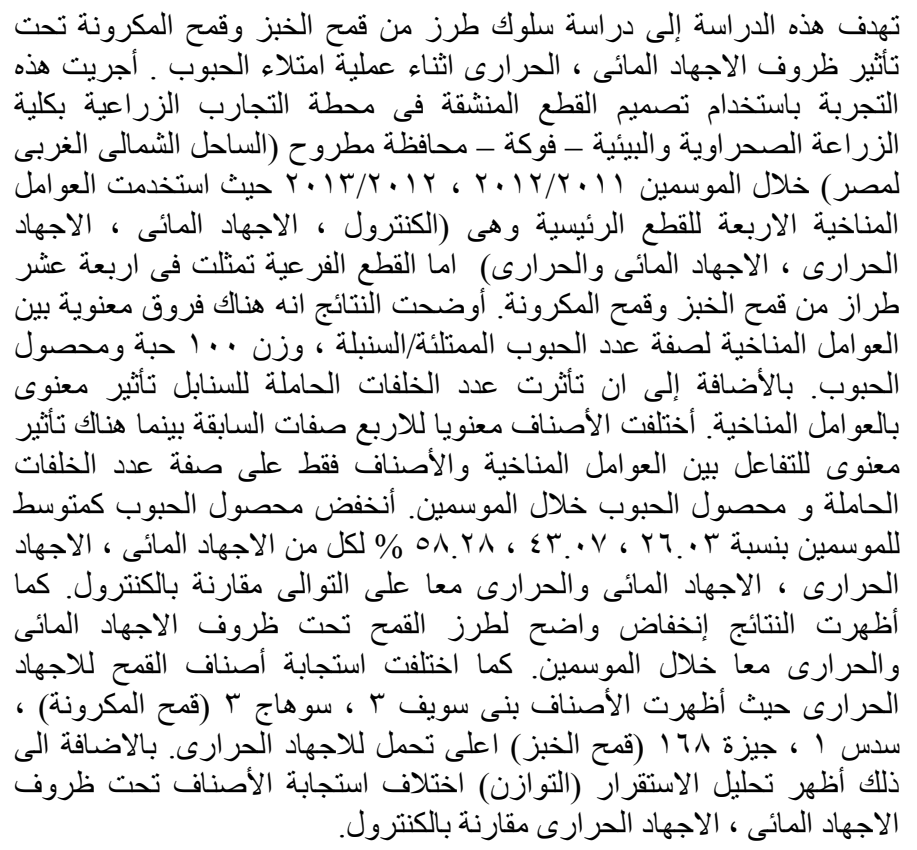

